\title{
Evaluation of technologies and resources from the spatial and social aspect
}

\author{
János Nagy - Botond Sinóros-Szabó \\ University of Debrecen Centre for Agricultural Sciences, Debrecen \\ nagyjanos@agr.unideb.hu
}

SUMMARY

\begin{abstract}
The basic functioning of the world is mostly led by negative trends. One of the fundamental reasons for this phenomenon is that the different technologies (hardware, software, resources) do not act properly and in the proper structure by means of the produced products and services. Therefore, the examination of technologies and resources is a key question of our world and development from various aspects. Technologies convey all positive and negative impacts which can be regarded as the fundamental reasons and causes of harmonious or disharmonious development. For this reason, the role of technologies in development and harmonious functioning is of paramount importance.

As a final conclusion, we established that the different technologies (hardware, software, resources) are interpreted as impact conveyors which predominate by means of products and services in a way that their relation system is determined. By using the thermodynamic interpretation which is the basis of the functioning of the world, we built a system consisting of 14 elements to evaluate different technologies, to interpret its functioning and to develop positive interactions and trends.
\end{abstract}

Keywords: technology, resources, product, market, environment, society, energy

\section{ÖSSZEFOGLALASS}

A világ alapvetö müködését többségében és meghatározóan negativ trendek jellemzik. Ennek egyik alapvetö oka az, hogy a technológiák (hardware, software, eröforrás) nem megfelelö módon és megfelelö struktúrában fejtik ki hatásaikat az elöállitott termékeken és szolgáltatásokon keresztül. Így a technológiák és az eröforrások vizsgálata több szempontból is központi kérdése a világunknak, a fejlödésnek és a fejlesztésnek. A technológiák közvetítik azokat a pozitiv és negativ hatásokat, melyek a harmónikus vagy diszharmónikus fejlödés alapvetö okainak, okozóinak tekinthetök. Mindezek okán a technológiák fejlödésben, fejlesztésben, a harmónikus müködésben betöltött szerepe meghatározóan fontos.

Végső következtetésként megállapitottuk, hogy a technológiákat (hardware, software, eröforrások), mint a termékek és szolgáltatások révén érvényesülö hatás-közvetitöket értelmezzük úgy, hogy ennek kapcsolati rendszerét határoztuk meg. A világ müködésének alapjául szolgáló termodinamikai értelmezést is felhasználva, 14 elemböl álló rendszert épitettünk fel a technológiák értékelésére, müködésének értelmezésére és a pozitiv kölcsönhatások, trendek kialakitására.

Kulcsszavak: technológia, eröforrások, termék, piac, környezet, társadalom, energia

\section{INTRODUCTION}

The technological changes and the development of new and novel technologies during the past decades perfectly portray the rapid development and the unstoppable change which involves everything and everyone. The constant and accelerating changes occur in our world almost "invisibly". Their impacts can be perceived both directly and indirectly both in the human environment, the society or in the nature and the economy.

The identification and evaluation of technologies, changes and their processes cannot be separated from the resources used by these technologies, as well as the products and services which are produced as a result of the interaction of these technologies and resources.

The impacts conveyed by products and services can be both positive and negative. These impacts are continuous temporally, but the technologies and their ever-renewing variations produce their effect in the spatial environment. For this reason, the identification and interpretation of technologies, products and services can only be performed in the proper reference system.

\section{MATERIAL AND METHODS}

In order to interpret different technologies and their necessary resources, it is indispensable to evaluate our living space, the world in a comprehensive way.

In order to perform this interpretation and evaluation, we took the thermodynamic bases which span the functioning of the world as a bases; therefore, our world is a non-linear and non-balanced (but irreversible and finite) thermodynamic system. All changes have to be defined in this system and these changes and their effects have to be interpreted in this system.

The criteria of harmonious development were formulated in accordance with this system (SinórosSzabó, 2004; Dinya, 2010). Based on our formulation, harmonious development refers to the non-linear and non-balanced irreversible system of nature, society, economy and human environment - interpreted on the system sustaining heat theory basis - which strives to reach balance in all points of space, at every point of time and in every material and energetic relation and the system is expressed in the mutually presumed functioning effect of each element of the system. Harmonious improvement is the form of harmonious development activated by humans. 
Technological interactions have to be (and can be) interpreted from this scientific approach which provides a systematic framework. It is a very important task, since these technological interactions convey negative effects and result in negative output by means of their phenomena, processes and trends especially because they do not fit into the system of harmonious improvement and development.

Meadows et al. (1972) drew the world's attention to all these trend-like and negative changes in their scientific work entitled "Limits to growth". The scientific work which shook the work raised fundamental questions in 1972 and Meadows et al. (2002) still look for the answers. Their analysis and conclusions are especially differentiated; there are areas where significant progression can be observed. In several areas, there are no positive changes and in some cases, problems of global proportions increased even further. There is absolutely no doubt that this question and the answer to this question are among the most important issues, with special regard to the fact that even new perspectives see the light of day nowadays which have the potential of new solutions.

Altogether, the fact that the natural resources indispensable for producing products and services and for operating technologies, that their quality decreases and their service providing ability decreases can be considered a general truth and it is manifested in a negative trend of global proportion.

There are numerous practical examples for the fact that land shows a deteriorating tendency in terms of its physical, chemical, biological and colloidical characteristics. The arable land in Hungary decreased by nearly 300 thousand hectares in the last 30 years.

The quality of our waters also decreases and its available quantity is strongly restricted. Providing water in proper quantity and of satisfactory quality costs increasing amount of money and energy.

The gas composition of air changed in a negative way, plant and animal species and breeds perish rapidly, social conflicts are permanent and the limitless profit increase enlarge social tension, resulting in the reduction of the unity and cohesion of the society. Altogether, the increase of social tensions may lead to a breach in society which could eventually be pulled into pieces.

These few examples perfectly show the global importance of the question, as well as its timeliness and the necessity of adaptable, demonstratable and extensible solutions.

\section{THE ROLE OF TECHNOLOGIES}

The different technologies, more specifically, hardware, software and resources are of special importance, since these are the interactions which determine the quantity and quality aspects of products and services and they convey products and services to users and consumers. From the systematic aspect, it is important to note that the connection and structure of each technological element determines the characteristics and specific features of products and services, i.e., the effects which are conveyed by consumers and users (single persons) to the society, the economy and natural resources, as well as the natural environment (Figure 1).

Figure 1: Impact system of technology

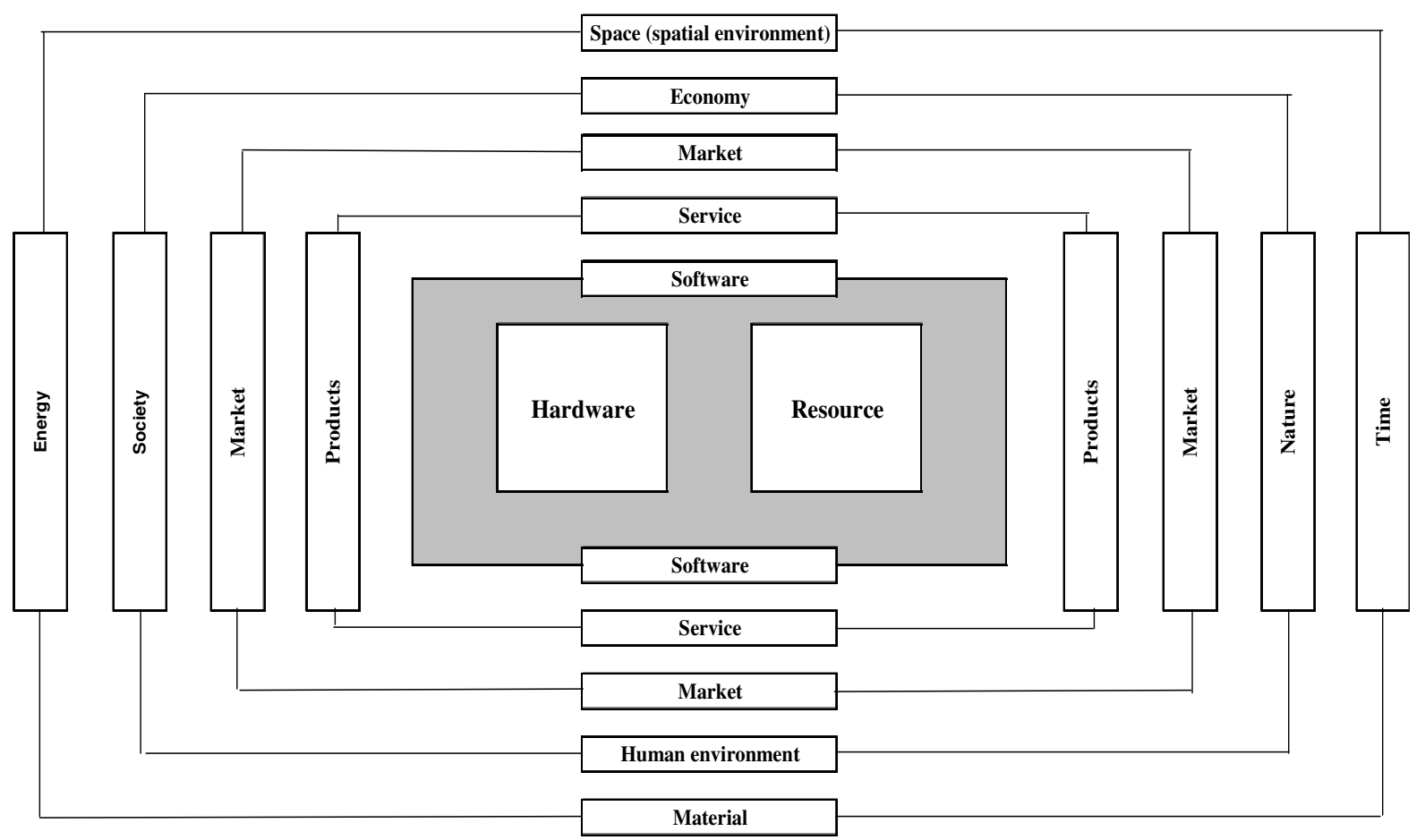

Source: own edition 
The system depicted in Figure 1 contains 14 units (elements) which constitute the world and which can also be interpreted individually. We define and present the structure of these elements which constitutes a system unit. This system demonstrates the unit in which technologies, products and services produce their specific effects and they can be interpreted through the harmony of the presented system.

If any of the 14 system constituents are interpreted independently of this system, the result will be undoubtedly false. The reason for the false result follows from the fact the extra impacts which constitute the operation of the 14 system constituents in a mutually presumed way and the harmony of the system are conveyed only by the whole system in its entirety.

\section{RESULTS AND CONCLUSIONS}

The examination of technologies and resources is a central question of our world, development and improvement from various aspects.

Technologies convey the positive and negative impacts which can be considered the fundamental reasons and causes for harmonious or disharmonious development. For this reason, the role of technologies in development, improvement and harmonious functioning is of chief importance.

The hardware elements of technologies represent the constant and renewable development and their materialised forms. For this reason, the software innovation capability of each generation has to be maintained, preserved and further developed. By emphasising the significance of technological software, great attention must be paid to the resources which are indispensable for the functioning of technologies, more specifically the various natural resources and materials. This is also necessitated by the fact the available amount of our natural resources (soil, water, air, etc.) has a decreasing tendency and their quality and service providing ability deteriorate. In a narrow sense, the technologies which depend on finite stocks (materials) raise the special and severe issue of the sustainability of products and services. In the broad sense, this issue refers to the sustainability of the harmonious functioning of social, natural, economic and human environments.

It is the uniform conclusion and result of analyses of different aspects that technological hardware, software and resources do not represent negative impacts or trends, but the wide, global scale system structure (which can also be evaluated in microregional spatial environments) whose systematic (structural) interactions are manifested in negative trends. (The results of the extremely high standard development of the computer is not questioned by any, while the structure of using it results in lots of negative outcomes - lack of human and social communication, individuals lose ground and get deformed, visual and joint problems, etc.)

As a final conclusion, we established that the different technologies (hardware, software, resources) are interpreted as impact conveyors which predominate by means of products and services in a way that their relation system is determined. By using the thermodynamic interpretation which is the basis of the functioning of the world, we built a system consisting of 14 elements to evaluate different technologies, to interpret its functioning and to develop positive interactions and trends.

\section{REFERENCES}

Dinya L. (2010): Bioenergetika rendszerszemléletben. [In: Gergely S. (szerk.) Zöldenergia, földhő és napenergia hasznosítása a hötermelésben.] Károly Róbert Főiskola. Gyöngyös. 25-32.

Gyarmati, I. (1970): Non-equlibrum Thermodinamics. (Field Theory and Variational Principles) Springer Verlag. Berlin-HeidelbergNew York. 1-184.
Meadows, D. H.-Meadows, D. I.-Randers, J.-Behrens, W. (1972): The Limits to Grouth. New York Universe Books. New York. USA

Meadows, D. H.-Randers, J.-Meadows D. I. (2002): A növekedés határai harminc év múltán. Kossuth Kiadó. Budapest. 1-318.

Sinóros-Szabó B. (2004): Technológia és fejlesztés I. Főiskolai Jegyzet. Nyíregyházi Főiskola Gazdaság- és Társadalomtudományi Kar. 1-159. 
